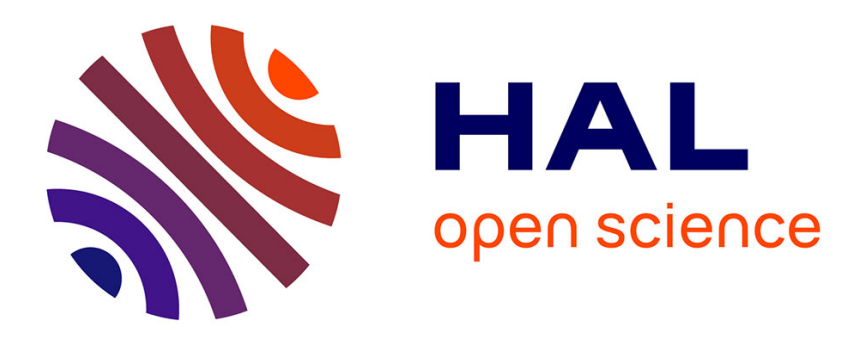

\title{
The move: When neurosciences teach us to better teach neurosciences
}

\author{
Marc Vérin, Pascal Benquet
}

\section{To cite this version:}

Marc Vérin, Pascal Benquet. The move: When neurosciences teach us to better teach neurosciences. Journal of the Neurological Sciences, 2018, 391, pp.149-150. 10.1016/j.jns.2018.06.002 . hal-01833890v2

\section{HAL Id: hal-01833890}

\section{https://hal-univ-rennes1.archives-ouvertes.fr/hal-01833890v2}

Submitted on 24 Oct 2018

HAL is a multi-disciplinary open access archive for the deposit and dissemination of scientific research documents, whether they are published or not. The documents may come from teaching and research institutions in France or abroad, or from public or private research centers.
L'archive ouverte pluridisciplinaire HAL, est destinée au dépôt et à la diffusion de documents scientifiques de niveau recherche, publiés ou non, émanant des établissements d'enseignement et de recherche français ou étrangers, des laboratoires publics ou privés. 
The Move: when Neurosciences teach us to better teach Neurosciences

Marc Vérin ${ }^{1,2,3}$ and Pascal Benquet ${ }^{3,4}$

1: Behavior and Basal Ganglia Research Unit (EA4712), University of Rennes 1, Rennes, France.

2: Department of Neurology, Rennes University Hospital, Rennes, France.

3: Institut des Neurosciences Cliniques de Rennes, Rennes, France.

4: INSERM U1099, LTSI, University of Rennes 1, Rennes, France. 
Although lecturing has been the predominant mode of instruction since the foundation of universities in Western Europe over most of a millennium ago, the traditional "teaching by telling" approach is now being undermined by the latest neuroscience and educational science data. In a well-designed recent meta-analysis published by Freeman et al (2014), 158 studies of student performance under active learning were compared with 67 studies under traditional lecturing. The results demonstrate that active learning increases both performance and motivation, and decreases failures. As Louis Cozolino points out in his book « The Social Neuroscience of Education » (2013): «While teachers may focus on what they are teaching, evolutionary history and current neuroscience suggest that it is who they are and the emotional environment in the classroom they are able to create that are the fundamental regulator of neuroplasticity ». The same conclusions are certainly applicable to the teaching of clinical neurosciences. Hundred thirty years after the important contribution of Jean-Martin Charcot in La Salpêtrière to education in neurology by changing abstract teaching into concrete teaching by putting his patients on stage during the lecture, Roze et al have implemented in the same place a novel learner friendly program: «The Move ». To modernize the teaching approach while making it accessible and fun for students, staging elements of the TV show The Voice were incorporated (such as teams, battles, coaches, and performing in front of a jury). The Move belongs to a broad category of simulation-based learning. Comparing the performance of the students that participated in The Move program with a standard education group of students, The Move clearly improves medical student's long-term retention and delayed recall (30 months) of neurological semiology. Why is the Move program so efficient, and why is it particularly relevant for learning clinical neurosciences? Modern neurosciences who are interested in the mechanisms of learning provide strong clues to understanding the efficiency of innovative programs such as The Move.

First, the hub-and-spoke model of semantic cognition suggests that multimodal, sensorimotor, cognitive and emotional engagement, as well as personal engagement, constitute the core 'ingredients' for constructing concepts. Active and multimodal memory processes are significantly more efficient than passive and modality-specific processes (Lambon Ralph et al, 2017). At neuronal and synaptic level, multiple inputs such as sensorimotor, cognitive and emotional stimuli might contribute to induce heterosynaptic plasticity by cooperativity and promote long-term potentiation and, at cognitive point of view, long-term retention.

Second, observing the symptoms to recognize and reproduce them mobilizes directly the mirror neuron system (Rizzolatti et al, 2016) and promotes empathy (de Waal et al, 2017), an essential capacity for future clinicians. Moreover, the activation of the mirror neuron system is clearly superior if the action seen has already been personally experienced by the subject himself. Thus the prior imitation of a symptom favors its later both recognition and understanding of the suffering it induces (Schütz-Bosbach et al, 2007).

Third, most stages of learning are influenced by a positive emotional context (attention, detection of novelty, memorization, motivation, choice and decision). Conversely, negative emotions have a deleterious influence on learning of neutral information (such as general knowledge). Thus anxiety has a negative impact on attention, memory and metacognition (Arnstem, 2015). The friendly context of the Move program and the competition in order to win student battles mobilize together the dopaminergic reward system and promotes motivation, desire to do, attention and memorization. In the same way, the fun context and the friendly competition also favor the pleasure and the desire to do again. So liking and wanting are favored positively by this program (Colasanti et al, 2012). Moreover, mobilization 
of the dopaminergic reward system contributes to promote both short and long term motivation (Howe et al, 2013; Westbrook et al, 2016).

The use of neuroscientific data is currently "à la mode" in the field of educational sciences. In the context of medicine learning, especially neurology, well conducted studies remain unfortunately rare. However, neuroscientists are particularly well placed to build this type of study, with a look at both innovative, because they are at the origin of the concepts newly highlighted, and critical regarding the cognitive processes and neuroanatomical substrates envisaged.

As a tribute to Jean-Martin Charcot, the inventor of Neurology, we must therefore thank Professor Emmanuel Roze's team for having taken inspiration from this great precursor both to put into practice the most modern concepts of learning, and to demonstrate their efficiency. Neurosciences still have a lot to learn from neurosciences themselves. 


\section{REFERENCES}

Freeman S, Eddy SL, McDonough M, Smith MK, Okoroafor N, Jordt H, Wenderoth MP. Active learning increases student performance in science, engineering, and mathematics. Proc Natl Acad Sci U S A. 2014 Jun 10;111(23):8410-5.

Louis Cozolino. The Social Neuroscience of Education. W. W. Norton \& Company, 2013, ISBN 978-0-393-70609-3, 440 pages.

Ralph MA, Jefferies E, Patterson K, Rogers TT. The neural and computational bases of semantic cognition. Nat Rev Neurosci. 2017 Jan;18(1):42-55.

Chistiakova M, Bannon NM, Bazhenov M, Volgushev M. Heterosynaptic plasticity: multiple mechanisms and multiple roles. Neuroscientist. 2014 Oct;20(5):483-98.

Rizzolatti G, Sinigaglia C. The mirror mechanism: a basic principle of brain function. Nat Rev Neurosci. 2016 Dec;17(12):757-765.

de Waal FBM, Preston SD. Mammalian empathy: behavioural manifestations and neural basis. Nat Rev Neurosci. 2017 Aug;18(8):498-509.

Schütz-Bosbach S, Prinz W. Perceptual resonance: action-induced modulation of perception. Trends Cogn Sci. 2007 Aug;11(8):349-55.

Arnsten AF. Stress weakens prefrontal networks: molecular insults to higher cognition. Nat Neurosci. 2015 Oct;18(10):1376-85.

Colasanti A, Searle GE, Long CJ, Hill SP, Reiley RR, Quelch D, Erritzoe D, Tziortzi AC, Reed LJ, Lingford-Hughes AR, Waldman AD, Schruers KR, Matthews PM, Gunn RN, Nutt DJ, Rabiner EA. Endogenous opioid release in the human brain reward system induced by acute amphetamine administration. Biol Psychatry. 2012 Sep 1;72(5):371-7.

Howe MW, Tierney PL, Sandberg SG, Phillips PE, Graybiel AM. Prolonged dopamine signalling in striatum signals proximity and value of distant rewards. Nature. 2013 Aug 29;500(7464):575-9.

Westbrook A, Braver TS. Dopamine Does Double Duty in Motivating Cognitive Effort. Neuron. 2016 Feb 17;89 (4):695-710. 